\title{
La militancia juvenil del partido Propuesta Republicana (PRO) en los centros de estudiantes universitarios*
}

The participation of «Propuesta Republicana» (PRO)

party's young activists in university student unions

\section{JUAN R. GRANDINETTI}

Universidad de Buenos Aires, Argentina

jgrandinetti@sociales.uba.ar

Este artículo se propone analizar las formas de participación, socialización política y reclutamiento de la militancia juvenil del partido Propuesta Republicana (PRO) en los centros de estudiantes de dos universidades ubicadas en la Ciudad de Buenos Aires: la Universidad de Buenos Aires y la Universidad Católica Argentina. Nos interesa examinar el modo en el que ciertos repertorios de acción y marcos de sentido se configuran a partir de la sociabilidad de los militantes y la cultura política de la organización. El artículo muestra que la cercanía (o lejanía) sociocultural y política de los militantes del PRO respecto a estos ámbitos permite entender las características de su inserción en la vida político-asociativa de cada una de estas universidades. Los hallazgos presentados se basan en un trabajo de campo llevado a cabo entre 2013 y 2015 en el que se utilizaron técnicas de investigación cualitativa tales como entrevistas en profundidad, observaciones directas en eventos partidarios y análisis de contenido de documentos y sitios web.

\section{Introducción}

Las universidades y sus centros de estudiantes han sido, históricamente, un espacio de participación central para las juventudes partidarias en Argentina. Así, ya desde los orígenes de los principales partidos argentinos, el mundo político y asociativo de las universidades se convirtió en uno de los más importantes ámbitos de inserción, socialización política y reclutamiento de su militancia juvenil.

Artículo aceptado para su publicación el 2 de mayo de 2019.

Este artículo se deriva de un proyecto de investigación doctoral sobre juventudes partidarias desarrollado en la Universidad de Buenos Aires entre 2013 y 2019, financiado a través de becas del Consejo Nacional de Investigaciones Científicas y Técnicas de Argentina (CONICET), la Universidad Nacional de Avellaneda, el Grupo Coimbra y el Gobierno de Canadá. 
Pasados los primeros años del retorno democrático, considerados como un período de reverdecer de la militancia y de la participación juvenil en los partidos políticos (Rodríguez, 2013; Vommaro y Larrondo, 2013; Vázquez et. al., 2017), el vínculo de las generaciones jóvenes con la política partidaria se caracterizó, durante la década del noventa y primera mitad de los dos mil, por el distanciamiento o el rechazo (Kozel, 1996; Sidicaro y Tenti Fanfani, 1998; Urresti, 2000). Diversos estudios se han encargado de señalar, para ese período, la emergencia de nuevas formas de participación y expresión política juvenil por fuera de la política institucionalizada, tanto en los movimientos sociales (Bonaldi, 2006; Vommaro y Vázquez, 2008; Vázquez, 2009) como en el ámbito de la producción cultural (Semán y Vila, 1999; Svampa, 2001; Cháves, 2007; Citro, 2008). Dentro del movimiento estudiantil, se constató la emergencia y consolidación de agrupaciones estudiantiles autodefinidas como «independientes» por su autonomía respecto a los partidos y los movimientos políticos nacionales (Picotto y Vommaro, 2010; Blanco, 2016; Palacios-Valladares, 2016).

Sin embargo, Argentina ha vivido durante la última década un proceso de revitalización de las organizaciones juveniles vinculadas a los partidos políticos (Borobia et. al., 2013; Natanson, 2013; Vázquez, Rocca Rivarola y Cozachcow, 2018). Así, no solo han surgido nuevos espacios juveniles partidarios, sino que estas militancias han ganado una gran visibilidad en el espacio público y en el discurso de la dirigencia política (Flax, 2013; Vázquez, 2013). A contramano de lo ocurrido en otros países de la región, se ha constatado en Argentina una recuperación relativa de los niveles de confianza de la ciudadanía en los partidos políticos, si se los compara con los de la década del noventa y los primeros años de los dos mil. Esta recuperación tuvo un mayor impacto entre las generaciones jóvenes ${ }^{1}$, que fueron exitosamente interpeladas y movilizadas por las organizaciones partidarias, sobre todo - aunque no únicamente- por aquellas ligadas al espacio político de la ex presidenta Cristina Fernández de Kirchner (2007-2015).

Estos fenómenos han despertado recientemente el interés académico, dando lugar a un fértil campo de estudios sobre militancias juveniles (Vázquez y Vommaro, 2012; Vázquez, 2014; Grandinetti, 2015, 2016, 2019; Vázquez y Cozachcow, 2017; Vázquez, Rocca Rivarola y Cozachcow, 2018). Sin embargo, mientras la relación entre los partidos y la participación política estudiantil en las universidades ha sido explorada por algunos trabajos enfoca-

Un estudio de la WVS muestra que los encuestados que confiaban mucho o bastante en los partidos políticos en Argentina eran el 8,2\% en 1995; 7\% en 1999; 7,6\% en 2006; y 15\% en 2013. Contra lo observado en ondas anteriores, en 2013 los jóvenes $(<30$ años) son quienes mayor confianza manifiestan $(17,2 \%)$. Disponible en http://www.worldvaluessurvey.org. Fecha de consulta: 05/02/2018. 
dos en décadas anteriores, especialmente en los años ochenta (Beltrán, 2013; Arriondo, 2015; Blanco y Vommaro, 2017; Yann, 2017), es poco lo que se ha estudiado sobre la inserción y la articulación de estas organizaciones juveniles partidarias en el mundo político y asociativo universitario actual.

En este artículo nos preguntamos por las formas de inserción, reclutamiento y socialización política de la militancia juvenil del partido Propuesta Republicana (PRO) en los centros de estudiantes de dos universidades ubicadas en la Ciudad Autónoma de Buenos Aires (CABA): una pública, gratuita y laica, la Universidad de Buenos Aires (UBA); y otra privada y confesional, la Universidad Católica Argentina (UCA).

A diferencia de otros partidos como la Unión Cívica Radical, el Partido Socialista o el Partido Comunista — cuyos anclajes en la universidad pública se remontan a comienzos del siglo $\mathrm{XX}$ - o del peronismo y las fuerzas de izquierda radicalizadas — que se insertan en la segunda mitad de ese sigloel PRO no solo es un partido nuevo, sino que sus principales dirigentes no han estado vinculados al movimiento estudiantil, ni poseen lazos durables con la vida política de las universidades públicas como la UBA.

Creado en 2003 bajo el nombre Compromiso para el Cambio, el PRO es el emprendimiento político del presidente argentino Mauricio Macri, por entonces empresario y dirigente del club Boca Juniors. En contraste con otros partidos surgidos luego de la crisis política y socioeconómica de 2001, el PRO no se reivindica heredero de ninguna tradición política ni es una escisión de un partido preexistente. Los orígenes y trayectorias de sus dirigentes se caracterizan por su heterogeneidad, al confluir en el partido empresarios y ejecutivos, técnicos del mundo de los think tanks y las ONG, y políticos provenientes tanto de los partidos tradicionales (el Partido Justicialista y la Unión Cívica Radical) como de otras fuerzas menores de centro-derecha. Dentro del elenco de nuevos jugadores del sistema partidario nacido luego de 2001, el PRO es el que más ha perdurado y más éxito electoral ha cosechado, llegando a gobernar la CABA desde 2007, y logrando hacerse en 2015 - a través de la alianza Cambiemos con la Unión Cívica Radical y otros partidos menores - de los ejecutivos de la Provincia de Buenos Aires, de algunas ciudades de esa provincia y de la Nación².

En este trabajo adoptamos un enfoque constructivista e interpretativo de la sociología política que propone estudiar a las organizaciones partida-

2 Para una caracterización general del PRO y sus cuadros dirigentes puede consultarse a Vommaro y Morresi (2014); sobre los orígenes y trayectoria del partido puede leerse a Vommaro y Morresi (2015); respecto al ingreso a la política de Mauricio Macri y la construcción de su liderazgo, a Mattina (2015); acerca del PRO en el marco de las derechas argentinas, a Morresi (2015) y Arriondo (2015); en cuanto a la participación de ejecutivos empresariales en el PRO, se recomienda el libro de Vommaro (2017); sobre el PRO como nuevo actor en el sistema político argentino luego de 2001, se sugiere leer a Mauro (2015). 
rias como el producto de las interacciones de sus miembros, y de esas organizaciones con otras organizaciones y grupos sociales (Lagroye, 1994; Offerlé, 2004). Nuestro interés se concentrará en examinar el medio social partidario (Sawicki, 1997; 2001; 2011) y los mundos sociales de pertenencia (Vommaro, 2015) de sus militantes. Este medio social se compone de circuitos de ámbitos de sociabilidad, es decir, de espacios de interacción perdurables, en los cuales los miembros de la organización partidaria desarrollan una socialización política continua (Bargel, 2009; Fillieule y Pudal, 2010; Fillieule, 2012; Fillieule, 2013). El enfoque que retomamos en este trabajo busca estudiar a la militancia en su carácter procesual (Sawicki y Siméant, 2009), atendiendo a las trayectorias de los militantes, sus procesos de politización y socialización política.

Es así que analizaremos la participación de los militantes juveniles del PRO en los centros estudiantes la UCA y la UBA entendidos como ámbitos de sociabilidad y reclutamiento. Mientras los centros de estudiantes de la UCA se encuentran débilmente articulados en términos organizacionales con el partido, tienen, en cambio, una alta relevancia para la comprensión de los mundos sociales de pertenencia de los militantes de Jóvenes PRO, ligados —según los resultados más amplios de nuestra investigación-a la sociabilidad católica de los sectores medio-altos y altos del Área Metropolitana de Buenos Aires (Grandinetti, 2016).

Por su parte, la militancia estudiantil del PRO en la UBA se encuentra formalmente vinculada al partido, y es un ámbito de reclutamiento de militantes juveniles y una vía de inserción del PRO en la principal universidad de Argentina. Sin embargo, se trata de un ámbito más distante, en términos socioculturales y políticos, para su núcleo de militantes y dirigentes juveniles.

Los resultados presentados en este artículo se basan en un trabajo de campo llevado a cabo entre 2013 y 2015 en la CABA, en el que realizamos veinte entrevistas en profundidad semi-estructuradas a dirigentes de Jóvenes PRO de la CABA, llevamos adelante observaciones de campo en diversos actos y actividades del PRO y Jóvenes PRO durante el período, y nos servimos del seguimiento y análisis de contenido de documentos internos y de diversas páginas de Facebook del PRO, Jóvenes PRO y de las líneas internas que la integran, incluidas sus agrupaciones universitarias. 
Juan R. Grandinetti

\section{«Estar cerca de los alumnos». Socialización política y reclutamiento partidario en los centros de estudiantes de la Universidad Católica Argentina.}

Los centros de estudiantes de la UCA resultan un ámbito significativo para comprender la socialización política de los dirigentes de Jóvenes PRO, además de uno de los ámbitos de reclutamiento de militantes juveniles en el partido y uno de los espacios de implantación del PRO entre jóvenes de sectores medio-altos y altos de Buenos Aires.

La UCA fue fundada en 1958 y depende del Episcopado de la Iglesia Católica de Argentina. Junto con la Universidad del Salvador, la Universidad Católica de Córdoba y la Universidad Católica de Santa Fe, es una de las primeras universidades privadas del país, creadas por iniciativa de entidades católicas inmediatamente después de la sanción de una ley que habilitaba por primera vez la gestión privada en la educación universitaria ${ }^{3}$. Actualmente, cuenta con sedes en la CABA, Mendoza, Paraná y Rosario. Desde los años noventa, su sede central se encuentra situada en el exclusivo barrio porteño de Puerto Madero, donde su oferta académica se distribuye en diez facultades. Según la información disponible ${ }^{4}$, cursan en la UCA 17.024 estudiantes a tiempo completo.

Como señala Rodríguez (2015b), desde sus orígenes, su proyecto institucional y pedagógico se propuso formar a la clase dirigente argentina y logró conformarse en un espacio de convergencia de la elite empresarial, terrateniente y política católica. Se trata, en este sentido, de una universidad nacida como una institución de y para las elites católicas tradicionales de Argentina que, a partir de los años ochenta, se constituyó en una opción educativa también para los sectores medio-altos y altos.

Tal como lo señalan Tiramonti y Ziegler (2008), se advierte en el sistema educativo argentino de las últimas décadas una tendencia a una creciente fragmentación y segregación, que da lugar a espacios de socialización cultualmente homogéneos, tanto de los sectores privilegiados como de los más desfavorecidos. Si bien el acceso a la educación universitaria (sea privada o pública) se encuentra de por sí restringido y estratificado socialmente, nos encontramos en la UCA ante un espacio relativamente homogéneo y segregado en términos sociológicos, que proporciona ciertas formas de so-

3 Tiene como precedente institucional a la Universidad Católica de Buenos Aires creada por el Episcopado Argentino en 1910 y cerrada en 1922, debido a la falta de reconocimiento estatal de sus títulos. Para una historia de la relación de la Iglesia Católica y el sistema educativo en Argentina puede consultarse Rodríguez (2015a) y Algañaraz (2018).

4 Dato proporcionado por QS World University Rankings, consultado por última vez el 16/ 01/2019 en: https://www.topuniversities.com/universities/pontificia-universidad-catolicaargentina. 
cialización a aquellos grupos que ocupan posiciones privilegiadas, en tanto la posibilidad de participar en él se encuentra material y simbólicamente reservada a los sectores medio-altos y altos en condiciones tanto de afrontar sus elevados costos económicos como, a su vez, de considerar este tipo de universidades dentro de su horizonte de expectativas y planes de vida ${ }^{5}$.

La vida político-asociativa de los estudiantes de la UCA en su sede de Buenos Aires se desarrolla en 13 centros de estudiantes organizados por facultad o departamento, entre los que se destacan por su mayor nivel de actividad y politización — según constatamos en nuestro trabajo de campolos centros de estudiantes de Derecho, y de Ciencia Política y Relaciones Internacionales. Los distintos centros, incluidos los 8 existentes en las sedes del resto del país, se encuentran nucleados en la Federación de Centros de Estudiantes de la UCA (FEUCA).

A diferencia de lo que ocurre en las universidades públicas argentinas, la capacidad de acción política de los estudiantes de la UCA se encuentra restringida por el marco normativo de la institución. En primer lugar, la participación explícita de los partidos políticos en la vida universitaria está prohibida y los centros de estudiantes son definidos en el Estatuto General de los Centros de Estudiantes como «asociaciones políticas apartidarias». Así, ninguna de las agrupaciones estudiantiles pueden mostrarse cercanas o alineadas a algún partido político. Esto, como veremos, no sólo implica límites a los partidos en su capacidad de inserción dentro de estos ámbitos, sino que da lugar a una especial relación de quienes participan de los centros de estudiantes con las organizaciones partidarias, y a la conformación de ciertas visiones acerca de la política partidaria. A su vez, limita implícitamente los alcances de las acciones llevadas a cabo por los centros de estudiantes, cuyas propuestas y reivindicaciones no pueden exceder lo académico y gremial. En segundo lugar, y también en contraste con las universidades públicas, los estudiantes no participan del gobierno de la Universidad y, por lo tanto, la representación estudiantil se reduce a un trabajo de cooperación con las autoridades en cuestiones vinculadas a las actividades extracurriculares y de convivialidad académica.

Resultado de estas limitaciones normativas, que cristalizan, a su vez, una cultura política dentro de la Universidad y sus centros de estudiantes, y de las limitaciones propias de la relativa segregación y homogeneidad de estos ámbitos, es que existen escasas relaciones de los centros de estudiantes

Sobre la homogeneidad social y la segregación espacial como criterios de elección de universidades privadas en jóvenes de sectores medio altos y altos de Buenos Aires, puede leerse a Fuentes (2017). Gessaghi (2015; 2016), por su parte, analiza la conformación de la "clase alta" como categoría social y principio de distinción moral, en su relación con las trayectorias educativas de las "familias tradicionales" argentinas. 
de la UCA con el movimiento estudiantil, siendo inexistente la articulación con los centros de estudiantes de las universidades públicas y, como veremos más adelante, muy débiles los vínculos entre los militantes de Jóvenes PRO que participan de los centros de estudiantes de la UCA y los integrantes de las agrupaciones del PRO en la UBA. Existen, en cambio, fluidas relaciones de los centros de la UCA con los de otras universidades privadas de elite como la Universidad Austral, la Universidad Torcuato Di Tella, la Universidad San Andrés y el Instituto Tecnológico de Buenos Aires, a través de la Asociación de Centros de Estudiantes de Universidades Privadas (ACEUP). De este modo, puede verse cómo el cierre social y la homogeneidad de ciertos espacios de socialización se reflejan también en las redes que entre ellos se establecen.

Cabe preguntarse, dada la prohibición de la política partidaria y el cierre social presente en estos espacios, bajo qué condiciones los partidos políticos pueden hacer de los centros de estudiantes de la UCA parte de su medio partidario, logrando el reclutamiento de nuevos militantes y adherentes.

Veamos, en primer lugar, cuál es la dinámica a partir de la cual se conforman las agrupaciones o listas que compiten (aunque no siempre se presente más de una a las elecciones) por los centros de estudiantes. A diferencia de lo que frecuentemente ocurre en las universidades públicas, e independientemente de la prohibición de la política partidaria, la lógica que regula la formación de agrupaciones en los centros de estudiantes de la UCA no tiende, en principio, a estructurarse en torno a la adhesión a ciertas identidades políticas ni a replicar las divisiones partidarias nacionales o locales, aunque sí existan agrupaciones que son percibidas por los estudiantes como cercanas a ciertos partidos o en las que sus integrantes sean públicamente conocidos como, al mismo tiempo, militantes de determinadas organizaciones partidarias.

En consecuencia, la dinámica de formación de grupos se encuentra regida principalmente por la afinidad entre amigos, las redes de relaciones interpersonales y las simpatías entre compañeros. Esto, como nos lo explicaron varios dirigentes de Jóvenes PRO que fueron presidentes de centros de estudiantes en la UCA, posibilita la formación de espacios integrados por estudiantes de diversas orientaciones políticas y, al mismo tiempo, dificulta la formación de verdaderas organizaciones que trasciendan en el tiempo a la conformación de una lista para las elecciones del centro de estudiantes.

En este contexto, serán las mismas redes informales que el partido pueda trazar con quienes integran los centros de estudiantes, la participación de militantes y referentes partidarios en la vida de la Universidad, las posiciones de liderazgo de los militantes partidarios entre sus demás compañe- 
ros de lista, y más ampliamente, la afinidad del partido y sus dirigentes con un electorado universitario mayoritariamente de origen católico y de clase media alta y alta, las que condicionen las posibilidades de inserción del partido en los centros de estudiantes, estableciendo relaciones duraderas con sus agrupaciones, y reclutando desde allí nuevos militantes.

En el caso del PRO, nos encontramos con que desde sus orígenes como partido tiene militantes al frente de las listas ganadoras del centro de estudiantes de la Facultad de Derecho, y tiene una importante presencia también en el centro de estudiantes de Ciencia Política y Relaciones Internacionales, convirtiéndose ambos en espacios de reclutamiento de militantes, algunos de los cuales integran o integraron el Comité Ejecutivo de Jóvenes PRO en la Ciudad de Buenos Aires, y hemos entrevistado en el marco de nuestra investigación. Ya en 2004, cuando el partido aún se llamaba Compromiso para el Cambio, una lista denominada Compromiso Estudiantil, encabezada por Francisco Quintana — quien sería luego presidente de Jóvenes PRO — ganaba el centro de estudiantes de Derecho. Desde aquel año hasta la actualidad, estudiantes ligados al PRO o a su coalición electoral en la CABA (Vamos Juntos) han presidido casi ininterrumpidamente ese centro de estudiantes. Debido a la prohibición de los sellos partidarios, a una censura más o menos generalizada a los alineamientos partidarios explícitos y a la falta de constancia en las denominaciones de las listas o agrupaciones, la participación del PRO en los centros de la UCA es más difícil de rastrear y mensurar que en la UBA, donde el PRO lleva agrupaciones con el nombre del partido. Así, la reconstrucción de la participación de militantes juveniles — que se da a título personal, más allá de que se articule con la militancia partidaria, como mostraremos - la hemos realizado a partir de nuestras entrevistas con informantes clave y de información disponible en la web. Así, por ejemplo, en el centro de estudiantes de Derecho, hemos constatado que desde la conformación del PRO hasta 2019, al menos 9 presidentes estaban vinculados a la militancia juvenil del partido ${ }^{6}$.

La cercanía sociocultural del PRO y sus dirigentes con la institución y sus estudiantes permite explicar el éxito de su inserción en los centros de estudiantes de la UCA. No sólo por la afinidad en las visiones políticas resul-

6 Entre ellos, algunos han desarrollado carreras ascendentes en el PRO y ocupan actualmente cargos en la función pública: Francisco Quintana (Diputado del bloque PRO en la Legislatura de la CABA), Alberto Czernikowski (Director de Juventud en la Provincia de Buenos Aires y ex candidato a Intendente de Malvinas Argentinas), Pablo Alaniz (Concejal del PRO en Florencio Varela), Agustín Sánchez Sorondo (Jefe de Gabinete del Organismo Provincial para el Desarrollo Sostenible de Buenos Aires), Jesús Acevedo (Secretario de Gestión Institucional de la Nación), José María Grippo (Subsecretario en la Jefatura de Gabinete de la Provincia de Buenos Aires), María Florencia Parietti (Directora General en la Jefatura de Gabinete de la Provincia de Buenos Aires). 
tante de una socialización en espacios comunes y de orígenes y trayectorias sociales convergentes, sino porque esa cercanía social se traduce también en redes informales, en presencia de militantes del partido o de adherentes potencialmente reclutables, que «abren las puertas» del centro de estudiantes a los dirigentes partidarios para dar charlas y participar de debates.

De este modo, el reclutamiento partidario de representantes estudiantiles o el ingreso de militantes de Jóvenes PRO en los centros de estudiantes reviste un interés para el partido y sus dirigentes, en tanto forma de implantación del partido en un ámbito de jóvenes de sectores medio-altos y altos, es decir, una forma de establecer un vínculo perdurable a través del cual hacer llegar sus propuestas de campaña, darse a conocer y recibir invitaciones a charlas, debates y foros, organizados por los centros de estudiantes de la Universidad. Al mismo tiempo, los centros de estudiantes no sólo revisten un interés en tanto permiten establecer vínculos que «abren las puertas» de la Universidad a los dirigentes del PRO para hacer proselitismo de un modo no explícito, sino que sirven para el reclutamiento de jóvenes profesionales para la gestión de gobierno y de nuevos militantes formados y con un alto grado de afinidad sociocultural con el partido.

Asimismo, estas charlas y debates, que son las actividades más eminentemente ligadas con la política partidaria entre las que realizan los centros de estudiantes de la UCA, se presentan como instancias de socialización política para los estudiantes, no tanto por el contenido de las mismas, sino porque implican la posibilidad de un contacto directo con políticos y dirigentes partidarios. Así, especialmente para quienes participan activamente de los centros de estudiantes, la organización de estos encuentros los pone en contacto directo con el mundo de la política partidaria. En este sentido, la participación activa en los centros les permitió a los militantes entrevistados tanto acercarse al PRO a partir de escuchar a sus dirigentes y contar con contactos en el partido producto de la organización de actividades en el centro de estudiantes, como recibir invitaciones a actividades partidarias y en algún caso ofertas de trabajo en la administración pública— producto de su condición de representantes estudiantiles. Un dirigente que ingresó a la militancia juvenil en los orígenes del PRO a partir de presidir un centro de estudiantes de la UCA relata en estos términos su entrada al partido:

«En 2003 estaba activamente en el Centro de Estudiantes cuando se hizo este ciclo de charlas aproveché para escuchar a distintos candidatos, me acuerdo por ejemplo que estuvieron Aníbal Ibarra, Elisa Carrió y el propio Mauricio [Macri], y mi recuerdo es que post ciclo de charlas tomé la decisión de acercarme a Compromiso Para el Cambio [PRO], sin conocer más que al contacto con el que ha- 
bíamos llevado a Mauricio [Macri] a la Facultad, digamos. Porque ni siquiera era mío, era un contacto del Centro de Estudiantes, pedí el contacto y lo llamé para decirle que tenía ganas de sumarme y acercarme sin tener absolutamente ningún conocido dentro del partido.»- Lucas ${ }^{7}$.

Aun así, la socialización política resultante de la participación en los centros de estudiantes no se agota en los vínculos que potencialmente establezcan sus integrantes con los dirigentes partidarios y el capital social que puedan adquirir desde allí. La experiencia de participar en un centro de estudiantes proporciona también a estos jóvenes una serie de conocimientos prácticos, destrezas y esquemas interpretativos que los preparan para la práctica política, tanto porque los entrenan en tareas luego recuperables en su militancia partidaria, como porque les proporcionan un sentimiento de auto-habilitación para involucrarse y asumir posiciones de liderazgo. Así, la experiencia de conformar una lista, de distribuir cargos, de llevar adelante una campaña electoral, el hecho de asumir roles de representación colectiva, de establecer extendidas redes interpersonales con estudiantes, de tener una relación más fluida y desde el lugar de representantes estudiantiles con las autoridades de la institución, entre otros, expone a estos jóvenes a una serie de prácticas capitalizables en la militancia partidaria.

A su vez, la participación y liderazgo en un centro de estudiantes se convierte en una situación estratégica movilizable en la construcción de una carrera ascendente en el partido. En su doble rol de militantes partidarios y representantes estudiantiles, estos jóvenes garantizan la presencia del PRO en la vida universitaria de la UCA y, fundamentalmente, ponen sus redes de contactos dentro del mundo estudiantil al servicio del reclutamiento partidario. Esto los dota de prestigio al interior de la juventud partidaria, en tanto nutren sus filas con nuevos militantes. Como ya hemos mencionado, la tarea de reclutamiento no sólo se concreta a partir de la presencia de militantes en los centros, sino que se ve propiciada por la cercanía sociocultural del PRO y los estudiantes de la UCA, algo que es percibido por algunos militantes como una «afinidad natural»:

«Empecé a tener más relevancia dentro de la Juventud del PRO porque había acercado a mucha gente (...) [Luego de entrar al PRO]

Lucas estudió en un colegio católico jesuita ubicado en Recoleta. Se recibió de Abogado en la UCA. Se acercó al PRO (que aún se llamaba Compromiso para el Cambio) en 2003, a partir de sus tareas como Presidente del Centro de Estudiantes de su Facultad. Ocupó un cargo jerárquico en el Gobierno de la Ciudad de Buenos Aires y actualmente desempeña un cargo electivo en la CABA. 
empiezo a nutrirme del centro de estudiantes y de un montón de estudiantes para sumarlos al PRO, empiezo a ver que naturalmente por la Facultad había una afinidad con el PRO y con Macri (...) Se daba natural, no sé muy bien decirte la razón, pero supongo que, quizás más antes que hoy, pero en ese momento si cruzabas los votos de los estudiantes de la UCA de Derecho en las elecciones de la Ciudad de Buenos Aires, te hubiera dado que un alto porcentaje de ese electorado era para Macri.»- Javier ${ }^{8}$.

El interés del partido en estar presente en los centros no se debe exclusivamente a la posibilidad de conseguir nuevos militantes y difundir sus ideas, sino a que esta «presencia» en las universidades es leída al interior de la organización como un indicador de fuerza política y de cercanía del partido con los jóvenes. Así, aquellos militantes que hacen posible que el partido pueda mostrar que está presente en muchas facultades, pueden capitalizar y hacer valer ese logro ante la dirigencia partidaria. Para aquellos militantes del PRO que participan o participaron de los centros de estudiantes de la UCA, la potencial conversión en su carrera militante del capital social y político acumulado en esa experiencia estudiantil, funciona como una retribución a su participación, y aún siendo prácticas formalmente desvinculadas de la vida partidaria, son de hecho capitalizadas y puestas en valor al interior del partido.

Así lo describe un dirigente juvenil que participó activamente en la vida político-asociativa de la UCA:

«En la política hay mucho gesto simbólico, de decir: tenemos 5 universidades, tenemos $6 \ldots$ que por ahí no es nada, pero el símbolo es muy fuerte, de decir: iWow! Mirá, el PRO está en 9 universidades (...) Antes los más politizados estaban en el partido político y nada más, hoy empezó a garpar [a resultar rentable] estar en las [universidades] privadas (...) entonces al tipo que está más politizado le sirve como una herramienta para su referente, para decir: che, mirá, yo te gané el centro de Derecho o el centro de Políticas.» - Javier.

Si bien sabemos que los centros de estudiantes de la UCA no son el único ámbito de socialización política de los militantes y dirigentes juveniles

Javier estudió Derecho en la UCA, donde además fue Presidente del Centro de Estudiantes. Como parte de sus tareas de representante estudiantil en la UCA, conoció en 2008 a un referente de la juventud partidaria que lo invitó a militar en el PRO. Trabaja como asesor en un despacho legislativo y colabora en la estrategia de comunicación del PRO en el interior del país. 
del PRO entrevistados que estudiaron en esa universidad, resulta interesante la afinidad existente entre las prácticas (y las visiones de los militantes acerca de esas prácticas) en los centros de estudiantes y en el PRO. Esta afinidad permitiría explicar el pasaje fluido y sin conmociones de la participación estudiantil a la militancia partidaria, y viceversa.

En primer lugar, encontramos en el PRO y en los militantes de Jóvenes PRO, una concepción de la política muy ligada a la idea de "gestión», a una resolución pragmática de problemas que va más allá de cualquier ideología, considerada como una «mochila» como algo que «te ata» y restringe la capacidad de acción. La política resulta, para los jóvenes del PRO — aunque esto lo comparten con el discurso de sus dirigentes - una gestión no ideológica de problemas concretos de la «gente» (Grandinetti, 2015). Si bien los partidos políticos son bien valorados en términos abstractos, la política partidaria tradicional es entendida como una vieja forma de hacer política, como «la política del pasado».

Cuando consideramos el modo en el que conciben su participación en los centros de estudiantes, encontramos una fuerte sintonía con estas visiones. A pesar de que aquello que hacen o hacían en los centros les resulta, en palabras de un militante, «algo completamente distinto» a la militancia partidaria, su descripción de esas prácticas como orientadas a estar «cerca de los alumnos» y a ayudarlos a resolver problemas de su vida cotidiana, o de las agrupaciones estudiantiles como espacios no ideológicos dirigidos a la gestión de asuntos concretos, resultan afines con aquellas concepciones de la política:

«Tenés un matiz enorme de gente, porque el trabajo que ellos hacen [en el centro de estudiantes] no tiene nada que ver con la partidización de la política, es un trabajo específico, en la Facultad, de estar cerca de los alumnos (...) Para mí el centro de estudiantes es [así:] vos te juntas con un equipo de gente que no importa si son afines a Mauricio Macri, o a Cristina Kirchner, o a Alfonsín, no importa, lo importante es qué buscamos, y buscamos [por ejemplo] que la gente en la mesa de entradas pierda menos tiempo, perfecto ¿Cómo lo hacemos? Así, así y así [...] Siempre con propuestas muy chicas, y la verdad es que la Facultad nos ayuda mucho, porque nosotros lo planteamos, la Facultad responde, tiene buena onda con nosotros.»- Matías ${ }^{9}$.

Matías hizo su secundaria en un colegio católico de una ciudad de la Provincia de Buenos Aires. Estudió Derecho en la UCA, donde presidió el Centro de Estudiantes. Empezó a militar en el PRO durante 2009, luego de contactarse a través de la página de Facebook de Jóvenes PRO. 
El carácter limitado de la capacidad de acción en los centros de estudiantes se encuentra dado por sentado y naturalizado. Ninguno de los entrevistados manifestó disconformidad respecto a que no pudieran abordarse asuntos políticos de más amplio alcance o que los partidos no pudieran participar de la vida estudiantil. En este sentido, se percibe cierto acuerdo respecto a la legitimidad de las competencias de los centros de estudiantes, que posibilita una relación de cooperación y trabajo conjunto con las autoridades universitarias, actitud que contrasta con la tradición contestataria de la política estudiantil en las universidades públicas.

Otro elemento muy presente en las entrevistas que hemos realizado y en el discurso del PRO acerca de sí mismo, es aquello que llamaremos aquí una presentación de sí pluralista. Esta concepción permite amalgamar positivamente la idea de una política entendida como gestión de asuntos concretos, como solución eficiente de «problemas de la gente» sin condicionamientos ideológicos y como «servicio», con la diversidad de orígenes políticos de los dirigentes del partido. Esta heterogeneidad de afiliaciones y tradiciones políticas es leída desde este ethos como una riqueza, como un signo de pluralismo democrático y apertura que demuestra que las ideologías y las viejas tradiciones políticas no tienen demasiado valor cuando de lo que se trata es de llevar adelante una gestión eficiente y estar «cerca de la gente». La presentación de sí pluralista confluye, así, con un ethos del hacer, que Vommaro (2015) identifica como parte fundamental del ethos político del PRO.

De este modo, una de las características distintivas de esta visión acerca de la política, muy presente entre los militantes entrevistados, es la de una valoración positiva de esta diversidad, entendida como una forma de superación de ideologías e identidades caídas en desuso, y de un espacio en el que priman los valores del diálogo y el consenso entre diversas posturas. En sintonía con el ethos pluralista y del hacer, presente en el PRO y que legitima su heterogeneidad y flexibilidad ideológica, la experiencia de participar en espacios políticamente heterogéneos, donde lo fundamental es «hacer un buen trabajo» de gestión y no construir identidades políticas comunes, es presentada - desde el relato retrospectivo de quienes actualmente militan en el PRO— como enriquecedora y formativa.

\section{«Un ambiente hostil». La dificultosa implantación del PRO en los centros de estudiantes de la Universidad de Buenos Aires.}

Si los centros de estudiantes de la UCA eran un ámbito socioculturalmente cercano a los militantes de Jóvenes PRO, donde se encontraban con su electorado «natural» y donde podían con relativa facilidad ubicar estu- 
diantes propios en las listas de las agrupaciones de los centros de estudiantes y reclutar nuevos militantes para el partido, los centros de estudiantes de la UBA aparecen, en los relatos de aquellos militantes entrevistados que participan o participaron de dichos espacios, como un terreno «hostil», en el que les resulta difícil insertarse y cosechar éxitos electorales.

Fundada en 1821, la UBA es la segunda universidad más antigua del país. Sus facultades se encuentran en la CABA, con algunas sedes ubicadas también en el Área Metropolitana de Buenos Aires. Con 262.932 estudiantes de grado, según el censo de 2011, es la universidad más grande del sistema universitario argentino. Es una universidad nacional, autónoma, laica, de gestión pública y gratuita en sus carreras de grado. El inicio de su movimiento estudiantil se da hacia finales del siglo XIX y tiene como principal hito el proceso reformista iniciado en 1918 en la Provincia de Córdoba (Walter, 1968; Buchbinder, 2010). La vinculación, más o menos solapada, de las agrupaciones estudiantiles con los partidos y movimientos políticos nacionales se remonta a los orígenes de la vida política de la universidad, con la presencia de agrupaciones ligadas a la Unión Cívica Radical (UCR), al Partido Socialista (PS), al Partido Comunista (PC) y al anarquismo, dentro del espectro político conocido como reformismo, por su reivindicación de la Reforma Universitaria de 1918. También, sectores de la Iglesia Católica, del peronismo y de la izquierda radicalizada participaron de la vida política de la universidad, a partir de la segunda mitad del siglo XX (Califa, 2014).

La historia más reciente del movimiento estudiantil en la UBA se asocia al regreso de la democracia en 1983 y estuvo signada en sus dos primeras décadas por la hegemonía de la agrupación de la UCR, Franja Morada (Beltrán, 2013; Yann, 2017). Los años noventa y comienzos de los dos mil se caracterizaron, a su vez, por una ola de movilizaciones en contra de las reformas neoliberales y los recortes presupuestarios impulsados por el gobierno de Carlos Menem (1989-1999). La crisis socioeconómica y política de 2001, que implicó la salida del gobierno de la UCR, conllevó el eclipsamiento de su agrupación estudiantil y la emergencia de espacios de izquierda «independientes» (Picotto y Vommaro, 2010; Blanco, 2016) y de agrupaciones vinculadas al trotskismo.

De un modo esquemático, las agrupaciones que componen actualmente el movimiento estudiantil de la universidad se dividen entre aquellas que se autodenominan «reformistas» (vinculadas a la UCR y al PS), las «nacional-populares» (ligadas al peronismo y a espacios kirchneristas), las «independientes» (agrupaciones generalmente de izquierda no vinculadas a partidos políticos) y las «trotskistas» (ligadas al Partido Obrero y al Partido de los Trabajadores Socialistas, entre otros). El PRO, un partido de creación reciente y poco vinculado a la historia del movimiento estudiantil, puede ser 
ubicado dentro del campo de la centro-derecha liberal, cuyo principal y más directo antecedente en la UBA fue la agrupación UPAU, ligada al partido liberal de derecha UCeDe, que cosechó importantes éxitos electorales en los años ochenta (Talento, 1988; Arriondo, 2015).

Como en el resto de las universidades nacionales, los estudiantes no solo están habilitados a elegir a sus representantes gremiales en los centros de estudiantes, sino que también eligen a los integrantes del claustro estudiantil en el gobierno de la universidad y de las facultades. Los centros de estudiantes de las distintas facultades se encuentran, a su vez, agrupados en la Federación Universitaria de Buenos Aires (FUBA), que integra la Federación Universitaria Argentina (FUA), junto al resto de las federaciones provinciales.

Lejos de la buena convivencia, la falta de conflictos, las actividades reducidas a lo estrictamente gremial, la cooperación con las autoridades y, en algunos casos, la ausencia de competencia electoral que caracterizan a la participación estudiantil en la UCA, la UBA es percibida por los militantes de Jóvenes PRO como su reverso: se trata de una universidad «muy politizada» $\mathrm{y}$ «partidizada», poblada de agrupaciones que exceden lo meramente estudiantil y que se encuentran ya consolidadas dentro una política universitaria signada por una dinámica contenciosa y conflictiva.

Los militantes del PRO atribuyen sus dificultades para insertarse en la vida política de la UBA y militar en sus centros de estudiantes a dos factores: por un lado, a la presencia de agrupaciones políticas ya consolidadas que manejan desde hace décadas los centros de estudiantes (especialmente aquellas vinculadas a la Unión Cívica Radical como Franja Morada y Nuevo Espacio, y al Partido Socialista como Nuevo Derecho) y frente a las cuales resulta difícil abrirse un lugar y, por otro lado, a la existencia de un estudiantado socialmente más heterogéneo que el de la UCA, cuyas preocupaciones y problemáticas socioeconómicas serían menos permeables al discurso del PRO, y que, además, porta una serie de «prejuicios» respecto a este partido, percibido como de derecha e impulsor de la privatización de la educación pública. Una militante de PRO-Derecho, la agrupación del PRO de la Facultad de Derecho de la UBA, familiarizada también con el mundo de la UCA, explica en estos términos las diferencias entre estas universidades y las dificultades con las que se encuentran en la UBA para insertarse políticamente:

«El de la UCA es un público más fácil... ahí sí entra el estereotipo, es un público que vota al PRO, el pibe que va a la UCA, me pasó con mis compañeros de colegio, tenía compañeros que iban a la UCA y que no sabían cómo se ponía la subtecard en el subte, son 
gente que vive en otro estrato social, con otras necesidades, que no son las que puede llegar a tener un pibe de la UBA (...) A ver, cómo decirlo sin que suene violento... hay muchos que nos votan porque piensan que es cool o porque no es tan político como los demás, entonces, como hay gente que le molesta la política, nos vota a nosotros y ese es el electorado más fácil que tenemos nosotros, que se puede ver mucho más reflejado en la UCA que en la UBA. En la UCA la problemática de muchos pibes es a dónde me voy a ir de vacaciones en enero y en la UBA es cómo hago para comprar estos apuntes, entonces son dos realidades distintas en las que claramente se nota más el prejuicio que nos tienen a nosotros en la UBA que en la UCA.»- Laura ${ }^{10}$.

Esta lejanía social y política del PRO con el mundo de la política estudiantil de la UBA se manifiesta, además, en el poco interés que ha demostrado el partido en implantarse en esta universidad hasta hace apenas unos pocos años. Así, mientras en la UCA la inserción de sus militantes ocurrió muy tempranamente (como vimos, ya en 2004 un militante juvenil llegaba a la conducción del centro de estudiantes de la Facultad de Derecho), la llegada del PRO a la UBA se dio recién en 2008 y se centró fundamentalmente en la agrupación PRO-Derecho, la primera en ser creada, cuya primera lista se presenta en 2009. Mientras se presentaron listas en forma esporádica desde 2010 en la Facultad de Ciencias Sociales sin que llegara a conformarse un grupo estable de militantes, recién en 2012 lograron formar una agrupación en la Facultad de Ciencias Económicas, que se presentó por primera vez en las elecciones de 2013. Ese mismo año se conforma la agrupación en la Facultad de Ingeniería, y un año después en la Facultad de Ciencias Exactas y Naturales, y en la Facultad de Arquitectura, Diseño y Urbanismo. De las 13 facultades de la UBA, entre 2009 y 2015, el PRO presentó listas en 6 de ellas. Solo en la Facultad de Derecho lo hizo en forma ininterrumpida desde aquel año. Según algunos de los militantes entrevistados, el buen resultado en la Facultad de Arquitectura y cierto crecimiento en algunas facultades como Derecho o Económicas en 2015, ha despertado un mayor interés en la dirigencia del partido por conquistar espacios en los centros de estudiantes de esta universidad.

10 Laura se contactó en 2011 con Jóvenes PRO a través del Facebook. Antes, había ingresado a una Dirección del GCBA a través de una amiga de su madre. Pasó por la carrera de Ciencia Política y actualmente estudia Derecho en la UBA, donde también milita y colabora en las campañas de distintas facultades. Antes de entrar a la política participó del grupo de jóvenes de una parroquia. 


\section{Tabla 1}

Posición y porcentaje de votos obtenidos por las listas del PRO en las elecciones de los centros de estudiantes de la UBA por facultad

(2009-2015).

\begin{tabular}{|l|c|c|c|c|c|c|c|}
\cline { 2 - 8 } \multicolumn{1}{l|}{} & 2009 & 2010 & 2011 & 2012 & 2013 & 2014 & 2015 \\
\hline Derecho & $\begin{array}{c}5^{\circ} \\
(7,5 \%)\end{array}$ & $\begin{array}{c}6^{\circ} \\
(4,57 \%)\end{array}$ & $\begin{array}{c}4^{\circ} \\
(10,37 \%)\end{array}$ & $\begin{array}{c}4^{\circ} \\
(8,23 \%)\end{array}$ & $\begin{array}{c}3^{\circ} \\
(6,28 \%)\end{array}$ & $\begin{array}{c}3^{\circ} \\
(10,6 \%)\end{array}$ & $\begin{array}{c}3^{\circ} \\
(12,76 \%)\end{array}$ \\
\hline $\begin{array}{l}\text { Ciencias } \\
\text { Sociales }\end{array}$ & - & $\begin{array}{c}10^{\circ} \\
(1,18 \%)\end{array}$ & - & $\begin{array}{c}10^{\circ} \\
(1,09 \%)\end{array}$ & - & $\begin{array}{c}9^{\circ} \\
(1,83 \%)\end{array}$ & - \\
\hline $\begin{array}{l}\text { Ciencias } \\
\text { Económicas }\end{array}$ & - & - & - & - & $\begin{array}{c}3^{\circ} \\
(6,28 \%)\end{array}$ & $\begin{array}{c}5^{\circ} \\
(6,34 \%)\end{array}$ & $\begin{array}{c}3^{\circ} \\
(8,73 \%)\end{array}$ \\
\hline $\begin{array}{l}\text { Ingeniería } \\
\text { Inquitectura, }\end{array}$ & - & - & - & - & $\begin{array}{c}4^{\circ} \\
(10,2 \%)\end{array}$ & $\begin{array}{c}4^{\circ} \\
(8 \%)\end{array}$ & $\begin{array}{c}5^{\circ} \\
(8 \%)\end{array}$ \\
\hline $\begin{array}{l}\text { Diseño y } \\
\text { Urbanismo }\end{array}$ & - & - & - & - & - & $\begin{array}{c}2^{\circ} \\
(11,5 \%)\end{array}$ & $\begin{array}{c}1^{\circ} \\
(32,6 \%)^{*}\end{array}$ \\
\hline $\begin{array}{l}\text { Cs. Exactas y } \\
\text { Naturales }\end{array}$ & - & - & - & - & - & $\begin{array}{c}6^{\circ} \\
(5,93 \%)\end{array}$ & - \\
\hline
\end{tabular}

Fuente: elaboración propia en base al portal Juventud Informada y páginas web de los centros de estudiantes.

* Se presenta en un frente con las agrupaciones Franja Morada, Reforma y Coalición denominado «Juntos por la FADU».

El nacimiento de PRO-Derecho y de PRO-Económicas, las agrupaciones de más larga data y que se encuentran mejor consolidadas en sus facultades, pareciera deberse más al emprendimiento propio de un grupo de militantes estudiantes de esas facultades que a una decisión estratégica del partido o de su organización juvenil de hacer pie en la UBA. Al menos en el relato de sus fundadores, estas agrupaciones parecieran haber sido el fruto de la aventura de un grupo de militantes de Jóvenes PRO que vieron una oportunidad para abrirse un espacio en el partido y en la política estudiantil a través de la presentación de listas del PRO a las elecciones de los centros de estudiantes y la posterior consolidación de un grupo de militantes. Así, si bien contaron con la autorización de Jóvenes PRO y del partido, los militantes que fundaron las agrupaciones de PRO-Derecho y PRO-Económicas lo hicieron con suficiente autonomía, ante un relativo desinterés del partido y su organización juvenil. 
A pesar de que el Comité Ejecutivo de Jóvenes PRO tiene una Secretaría que aglutina a las distintas agrupaciones universitarias del $\mathrm{PRO}$, conocida como PRO-Universidades, los militantes de la UBA entrevistados coinciden en que la pertenencia de PRO-Universidades a Jóvenes PRO se da «en los papeles», pero que existe una cierta desvinculación entre la organización juvenil y lo que ocurre en la UBA. Una de las dirigentes de aquel núcleo originario de PRO-Derecho atribuye la falta de involucramiento de Jóvenes PRO de la CABA en la conformación de las agrupaciones del PRO en la UBA al hecho de que, en su mayoría, los integrantes del Comité Ejecutivo de la organización juvenil pertenecían a la UCA y eran completamente ajenos a la dinámica política de la UBA y a su impacto en la política nacional:

«PRO-Universidades es muy distinto a Jóvenes PRO, tenemos intereses distintos, nosotros vamos más por la facultad, porque creemos que la política universitaria influye de otra manera dentro de la política, o sea, la izquierda se mantiene gracias al presupuesto que saca de la UBA y si le sacás ese presupuesto a la izquierda, quiero ver qué hacen en una campaña de la ciudad o una campaña nacional, es loquísimo pero influye en ese sentido... o mismo los radicales (...) Además los chicos [de Jóvenes PRO] que son de la UCA, claramente no van a entender lo que es la vida de la UBA.»Laura.

En este sentido, si bien existe un vínculo institucionalizado entre las agrupaciones del PRO en la UBA y la organización juvenil del partido, la distancia sociocultural del núcleo de militantes de Jóvenes PRO con el mundo de la política de esta universidad pública y su mayor cercanía con el mundo de las universidades privadas, especialmente de la UCA, ha tenido como efecto un cierto descuido de este ámbito, producto de una subvaloración de su importancia política y, posiblemente, de una sobrevaloración de las dificultades para insertarse, debido a su falta de vínculo con este ámbito y su vida política.

Una buena ilustración de la lejanía sociocultural y política de los militantes del PRO respecto a la política en la UBA es el intento de replicar dentro de la UBA repertorios de acción del partido más enraizados en el mundo social de los voluntariados y las ONG, y ciertas lógicas propias de universidades como la UCA en las que la utilización de sellos partidarios se encuentra vedada y los voluntariados forman parte de la formas de sociabilidad y participación habituales. Así, cuando se conforma en 2012 la agrupación del PRO en la Facultad de Ciencias Económicas, que luego se presentaría en las elecciones de 2013, deciden utilizar el nombre «Yo Estoy en 
Económicas», en lugar del nombre del partido. Ante la percepción de que presentarse con el sello partidario del PRO podría ser contraproducente, eligen alinearse con la estrategia comunicacional y de reclutamiento del partido y de su organización juvenil de aquel año, que consistió en un programa de voluntariado denominado «Yo Estoy». De este modo, estos militantes primerizos esperaban atraer el voto de los estudiantes de la UBA y reclutar nuevos integrantes para la naciente agrupación invitándolos a participar del programa de voluntariado que organizaba el partido, juntando papeles para reciclar y promoviendo una facultad «más sustentable». Las confusiones y ambigüedades que generaba en los estudiantes este tipo de estrategia, vinculada a un mundo ajeno a la política estudiantil de la UBA, los llevó a abandonar la denominación «Yo Estoy», para adoptar el año siguiente el nombre de PRO-Económicas, en sintonía con un ámbito en el que las agrupaciones universitarias se encuentran legítimamente vinculadas a los partidos políticos y tienden a reproducir la oferta partidaria dentro de la universidad. Uno de los militantes juveniles fundadores de PRO-Económicas con quien pudimos dialogar nos explica así esa primera experiencia fallida:

«Nos encontramos con el primer problema de la agrupación ¿Cuál fue? Que no entendían a qué estábamos, «Yo estoy en Económicas... ¿Qué hacen? ¿Actividad verde?»... Pensaban que estábamos reciclando, pensaban que íbamos en contra de los afiches, porque nosotros pusimos un banner que decía «Por una facultad sin volantes ni afiches, yo estoy en Económicas» (...) No servía lo que estábamos haciendo, entonces dijimos, acá hay que hacer un cambio de rumbo porque la gente no está entendiendo que nosotros venimos a trabajar por la Facultad y somos estudiantes de la Facultad, entonces fue ahí que dijimos «vamos a dejar el proyecto del partido de Yo Estoy, y vamos con nuestro propio nombre, independiente», y ahí fue PRO-Económicas (...) No entendían que nosotros estábamos haciendo política en la Facultad, creían que éramos una ONG.» - Luis ${ }^{11}$.

El caso de los orígenes de PRO-Económicas resulta ilustrativo de cómo las dificultades para la intervención de Jóvenes PRO en la vida política de la

11 Luis estudió en una secundaria católica de Villa del Parque, CABA. Empezó estudiar Economía en la UBA y como parte de un programa de pasantías, trabajó un tiempo en el GCBA. Luego de la pasantía se interesó por militar en Jóvenes PRO. En 2012, con otros compañeros de facultad que militaban en el PRO, armaron la agrupación PRO-Económicas. Participó muchos años en una ONG. Actualmente trabaja en una empresa privada. 
UBA se deben, en parte, al intento de valerse de un repertorio de acción y de marcos de sentido vinculados a otros ámbitos de sociabilidad, que funcionan adecuadamente en ellos, pero se muestran como ineficaces y hasta contraproducentes en el ámbito de la política estudiantil de la UBA. El intento de replicar las estrategias del partido en esta universidad, ante la falta de experiencia de estos militantes y el desconocimiento por parte del núcleo de dirigentes de Jóvenes PRO de las características de la actividad política en la UBA, llevó a este grupo de militantes a darse cuenta de que necesitaban reformular la presentación de su agrupación y adquirir un perfil más partidario.

El hecho de que, finalmente, todas las agrupaciones del PRO en la UBA adoptaron el nombre del partido seguido del nombre de la Facultad, les permitió valerse de la gestión de gobierno en la CABA como una plataforma para la construcción de una identidad propia y una estrategia de inserción en la vida política de la universidad y sus centros de estudiantes. Así, las agrupaciones «dan la cara» en nombre del PRO y del Gobierno de la CABA ante los estudiantes de la universidad, defendiendo la gestión gubernamental, difundiendo y comunicando sus políticas dentro de este ámbito, al mismo tiempo que intentan funcionar como intermediarios — según los militantes de PRO-Económicas, con poco éxito- entre el gobierno local, sus funcionarios, y las necesidades de los estudiantes, gestionando la instalación de bicicleteros para la Facultad y cestos de basura para reciclaje, entre otras cosas.

En este sentido, presentarse como parte del PRO tiene la ventaja, para estos militantes, de poder capitalizar los «logros» de la gestión pública en la CABA y conseguir cierta atención de los funcionarios para implementar algunas iniciativas, al mismo tiempo que les presenta dificultades ante un público (especialmente ante los militantes de las otras agrupaciones) que los percibe como de derecha y de un origen social acomodado. Así lo comenta una dirigente juvenil que participó de la agrupación PRO-Derecho desde sus comienzos:

«Al principio era un insulto atrás de otro, porque la Facultad de Derecho está muy politizada y es el socialismo el que tiene el centro desde hace ocho o nueve años, o más (...) Éramos tres, nos poníamos la remera amarilla, repartíamos volantes (...) La verdad es que lo que nos acompañó fue la buena gestión de Mauricio [Macri] en la Ciudad (...) Teníamos cosas con las que decir: esto que hicimos en la Ciudad... bueno, esto copado [positivo] que se hace en la gestión nosotros lo queremos traer pero para el ámbito de la Universidad. Y fuimos encontrando gente que por ahí simpatizaba con Mauricio [Macri] en 
lo que era la gestión y decía: bueno se puede bajándolo al ámbito universitario... y ahí se fue acercando gente.»-Alejandra ${ }^{12}$.

De este modo, la llegada del PRO al Gobierno de la CABA les permitió valerse de la gestión gubernamental para construir una presentación de sí basada en el «hacer». Así, por ejemplo, en el centro de estudiantes de la Facultad de Ciencias Económicas lograron acceder a la Secretaria de Espacios Verdes y desde allí reproducir políticas del programa «Ciudad Verde» del Ministerio de Espacio Público de la CABA para generar actividades vinculadas al reciclaje y la concientización ambiental. Desde la Facultad de Ingeniería, la agrupación del PRO organizó visitas guiadas para recorrer obras públicas del gobierno de Macri como el entubamiento del Arroyo Maldonado o la nueva sede del Gobierno de la CABA en Parque Patricios. PRO-Derecho llevó a militantes que trabajan en el programa «Primer Empleo» de la Dirección de Políticas de Juventud a dar talleres sobre armado de curriculum y entrevistas laborales. En algunas oportunidades, se invitaron funcionarios del Gobierno a dar charlas sobre temas que, en palabras de una militante, «sirvan a los estudiantes» en sus carreras. Por ejemplo, en 2013, en el marco de un ciclo de charlas llamado «Casos de estudio de empresas argentinas en Harvard», el en aquel momento- presidente del Banco Ciudad, Federico Sturzenegger, fue invitado por PRO-Económicas a hablar de su gestión en ese banco y Andrés Ibarra, entonces funcionario del Gobierno de la CABA y ex Gerente General de Boca Juniors durante la presidencia de Macri en el club, disertó en la Facultad sobre Boca como una «marca de proyección internacional, la innovación más audaz en la historia del futbol argentino», según lo describe la invitación al evento publicada en la página de Facebook de la agrupación.

Asimismo, los militantes del PRO en la UBA no sólo se encargan de defender y comunicar la gestión gubernamental, sino que adoptan ellos mismos un marco de referencia en el que «gestionar» ocupa un lugar igualmente protagónico en la presentación de sí y en el tipo de acciones llevadas a cabo en sus agrupaciones universitarias. Por ejemplo, en 2013 el slogan de campaña de PRO-Derecho fue «Elegí + Gestión» y en 2014, «Nosotros elegimos hacer. Votá a los que hacen». Al igual que los estudiantes de la UCA, los militantes del PRO en la UBA conciben su participación en la política universitaria desde un ethos de la gestión ${ }^{13}$ y desde una idea de la política

12 Alejandra comenzó su secundaria en un colegio público porteño y luego se cambió a uno privado católico, donde participó durante varios años de misiones en la Provincia de Buenos Aires. Llegó a Jóvenes PRO a través del Facebook en 2009. Se recibió de abogada en la UBA y militó en PRO-Derecho. Actualmente, también colabora como voluntaria en una ONG solidaria.

13 La idea de una política universitaria orientada a la prestación eficiente de servicios a los estudiantes tiene su antecedente en la UBA en la agrupación universitaria UPAU, ligada 
entendida como «dar un servicio»y «ayudar a la gente». Los volantes distribuidos por PRO-Derecho y subidos a su página de Facebook dicen «Acercate a nuestra mesa. Estamos para ayudar» y anuncian los distintos servicios y ayudas disponibles: «ayuda para superar el caos de las inscripciones, manual para rendir materias libres, mucha buena onda, guía para sacar el título de bachiller, ayuda con consultas del reglamento, recomendaciones de cátedras, manual para acelerar el trámite del título». En las mesas están disponibles, para los estudiantes que se acercan, calendarios de inscripciones, diagramas con las materias de las carreras, diversos materiales informativos, lapiceras del partido y caramelos.

De este modo, la mayor parte de sus acciones se orienta a brindar «servicios» a los estudiantes para facilitarle asuntos de índole estrictamente práctico. Por ejemplo, una de las principales actividades de PRO-Derecho consiste en brindar un servicio de fotocopiado gratuito para los estudiantes. En sintonía con esta idea, lanzaron también una aplicación para celulares dirigida a los estudiantes de abogacía, desde la cual se puede acceder a resúmenes, fallos judiciales y leyes. El objetivo, según nos explica una militante a la que entrevistamos, es «simplificarle más la vida» a los estudiantes.

Centradas en asuntos prácticos y cotidianos, las acciones y propuestas de las agrupaciones del PRO en la UBA apuntan a un tipo de estudiante «cansado de la política» en la Universidad y que vive con hastío lo que considera una excesiva politización que molesta e interrumpe el funcionamiento académico de la institución. Así, uno de los ejes de campaña del PRO en todas las facultades ha sido impugnar ciertas prácticas que conforman el repertorio típico de la política estudiantil en la UBA: la pegatina de carteles ( Si no viste gran cantidad de afiches nuestros es porque queremos una Facultad con las paredes más limpias», dice un volante publicado en el Facebook de PRO-Sociales) y el ingreso a las aulas para dar mensajes e invitar a actividades ( Si no nos ves en las aulas es porque no queremos interrumpir las clases vendiendo avisos sobre lo mismo de siempre», dice el mismo volante, mientras otro material de campaña de PRO-Sociales le recuerda a los estudiantes su «derecho a no ser molestados»).

Ya sea desde un llamado al orden (aparece con frecuencia la idea de «caos», «desorden», «suciedad») o desde un discurso de cuidado del medioambiente y de modernización («Yo estoy por una facu más moderna y sustentable», era uno de los slogans de PRO-Derecho en 2012), las agrupa-

al partido de centro-derecha UCeDe, que llegó a presidir cuatro centros de estudiantes hacia finales de la década del ochenta (Talento, 1988). Resulta relevante señalar que muchos dirigentes estudiantiles de la UPAU y dirigentes juveniles de la UCeDe del período 1982-1989 integran actualmente el PRO (Arriondo, 2015) y algunos de ellos sostienen vínculos con la agrupación PRO-Derecho. 
ciones del PRO en la UBA se distancian de los repertorios y lenguajes propios de las demás agrupaciones políticas de la Universidad, interpelando a un estudiante apolítico cuyo voto se conquista brindando servicios concretos (fotocopias, resúmenes, asesoramiento académico) y no molestándolo con cuestiones políticas.

El estudiante que el PRO interpela no está interesado en la discusión política —aún en facultades donde la discusión política forma parte del quehacer académico y del contenido de las carreras - sino en encontrar soluciones a problemas prácticos de su cotidianeidad como estudiantes (inscripciones dificultosas, baños sin papel higiénico, falta de wi-fi, ausencia de un menú para celíacos y vegetarianos en el comedor, etc.) y de su salida laboral. Un referente de PRO-Económicas lo explica en estos términos:

«Acá salís de cursar y ya te están molestando, entonces lo que se planteó hace dos sábados es por qué no proponemos que se haga un día, y solo un día, de votación en la Facultad, porque es toda la semana (...) Así, ahorrás papel, ahorras actividades de campaña que a la gente no le interesa, no quiere que la molestes, no quiere que le pongas un volante en la cara... los días de campaña en la Facultad son terribles (...) Por eso nuestra campaña va a ser en las redes sociales, no vamos a molestar al votante de Económicas, creemos que cuanto más seamos pesados, menos nos vas a votar.»- Luis.

Por otra parte, la «hostilidad» de la UBA, en comparación con la UCA o con el electorado general de la CABA, aparece para estos militantes una oportunidad para ejercitarse en la discusión política ante interlocutores formados y politizados, que requieren argumentos y tomas de posición más elaboradas que el ciudadano común. En este sentido, la militancia universitaria en la UBA brinda, según estos estudiantes del PRO, un ámbito en el cual desarrollar ciertas habilidades y saberes prácticos que consideran valiosos para su formación política y para su quehacer militante fuera de la Universidad. Así, la adversidad es resignificada como una ventaja comparativa, en tanto esperan capitalizar esta experiencia «hostil» en sus futuras carreras políticas.

\section{Palabras finales}

En este artículo nos propusimos examinar las formas de participación, socialización política y reclutamiento de los militantes juveniles del PRO en dos universidades dotadas de atributos sociológicos e institucionales dife- 
renciados. En una primera sección, hemos mostrado la relevancia de los centros de estudiantes de la UCA para el reclutamiento partidario y la socialización política de los militantes juveniles del PRO. En primer lugar, señalamos que se trata de ámbitos que les permiten, a los militantes juveniles que participan en ellos, adquirir saberes y destrezas utilizables en la militancia partidaria y ganarse cierto prestigio dentro del PRO en tanto referentes estudiantiles que «abren las puertas» de la UCA al partido y «acercan» a otros estudiantes al PRO, permitiéndoles establecer vínculos privilegiados con los dirigentes del partido y desarrollar carreras ascendentes en su organización juvenil. En segundo lugar, desde el punto de vista de la organización partidaria, evidenciamos que se trata de un ámbito fértil para el reclutamiento de nuevos militantes y jóvenes profesionales para la gestión de gobierno, al mismo tiempo que existe un interés de los dirigentes partidarios en contar con militantes propios en estos espacios, de modo de establecer un contacto fluido con la institución y participar frecuentemente en las charlas y debates políticos que se organizan en la Universidad.

Por su parte, en cuanto a la política universitaria de la UBA, hemos argumentado que la lejanía sociocultural del PRO y su organización juvenil respecto a ese ámbito permite explicar las dificultades que han tenido sus agrupaciones, hasta el momento, para insertarse con éxito en los centros de estudiantes y los espacios de representación estudiantil en las distintas facultades. A su vez, hemos mostrado cómo desde esta relativa ajenidad, los militantes del PRO han construido una presentación de sí basada en la gestión y la oferta de servicios al estudiante, al mismo tiempo que en la impugnación de ciertos repertorios y lenguajes propios de la política de la Universidad, interpelando a un estudiante hastiado de la política. Asimismo, hemos señalado el valor que le atribuyen los mismos militantes a esta adversidad $\mathrm{u}$ «hostilidad» de la política de la UBA para la adquisición de saberes y destrezas que marcarían un diferencial respecto a otros militantes acostumbrados a hacer política en espacios más afines.

En ambos casos nos hemos ocupado de analizar y comparar los repertorios de acción y los marcos de sentido a partir de los cuales estos militantes juveniles del PRO llevan adelante su participación en la vida políticoasociativa de cada universidad, en función de las formas de sociabilidad, la cultura política, las normativas y las características de la inserción del partido en cada institución. Hemos dejado de lado otros aspectos que podrían haber sido analizados también en clave comparativa como, por ejemplo, sus posicionamientos respecto a temas de debate público que nos hubieran permitido interrogarnos sobre la dimensión ideológica de esta militancia y su variabilidad en cada universidad. De todos modos, podemos afirmar, según la evidencia aportada por nuestro trabajo de campo, que no es esta dimen- 
sión la que mejor permite comprender las diferencias en la participación de los militantes del PRO en la UBA y la $\mathrm{UCA}^{14}$.

En el marco de un campo de estudios emergente y en crecimiento, consideramos que este trabajo ha realizado varios aportes. Por un lado, nos hemos ocupado de estudiar una militancia juvenil partidaria aún poco examinada por la literatura especializada, que se ha concentrado principalmente en la militancia juvenil kirchnerista. Por otra parte, hemos analizado las formas y condiciones de inserción en la vida política universitaria de un partido de centro-derecha ajeno a las tradiciones del movimiento estudiantil, al mismo tiempo que corrimos la mirada hacia espacios generalmente no estudiados por la literatura sobre participación estudiantil, como es el caso de los centros de estudiantes de las universidades privadas. Esto último, a su vez, creemos que nos ha permitido acercarnos, tangencialmente, al conocimiento de una de las formas de involucramiento y socialización política de los jóvenes de sectores socialmente privilegiados de Buenos Aires.

A través del análisis de la participación de los militantes juveniles del PRO en los centros de estudiantes de estas universidades, hemos podido explorar los modos en los que las sociabilidades de los agentes configuran ciertos repertorios de acción y marcos interpretativos que, al conjugarse con la cultura política de la organización, facilitan o dificultan su inserción en ciertos ámbitos de participación. En este sentido, hemos mostrado cómo la capacidad de una organización partidaria de expandir su medio social está, en mayor o menor medida, condicionada por las experiencias de sociabilidad de quienes participan en ella.

Aun así, nuestro trabajo supone un recorte sobre la sociabilidad de estos militantes juveniles, que no se agota en su participación universitaria. Vale señalar que la UCA es uno de los varios ámbitos en los que se desenvuelve la sociabilidad católica de muchos de los militantes juveniles del PRO de la CABA. En otro trabajo (Grandinetti, 2019) hemos analizado en profundidad la socialización política y el reclutamiento de militantes de Jóvenes PRO en voluntariados solidarios y misiones realizadas en instituciones católicas, especialmente instituciones educativas confesionales de sectores socialmente favorecidos.

Si bien estudiar ámbitos de sociabilidad resulta una estrategia productiva para entender cómo los miembros de ciertos grupos sociales adquieren determinadas disposiciones, el carácter complejo de las sociabilidades de

14 Nuestro trabajo coincide con algunos de los hallazgos de Binder y Wood (2013), quienes muestran cómo el contexto socio-institucional de los campus universitarios en Estados Unidos da forma a estilos y repertorios de activismo muy disímiles entre los jóvenes del Partido Republicano, aun cuando en términos ideológicos no presenten variaciones significativas. 
los agentes y su multi-posicionalidad en diversos ámbitos —incluido, en este caso, el ámbito partidario- nos obliga a ser prudentes al momento de analizar las relaciones entre pertenencia social, sociabilidades y prácticas. En este trabajo hemos procurado únicamente comprender las formas de inserción de los militantes del PRO en la vida político-asociativa de estas universidades. A través de este caso y de este recorte, sin embargo, esperamos haber contribuido también a reflexionar sobre estas complejas relaciones.

\section{Referencias bibliográficas}

Algañaraz, V. (2018). Universidad ¿Laica y pública o confesional y privada? La construcción de las universidades católicas en Argentina como espacios refractarios al reformismo universitario (1955-1958). Argumentos, 20, 44-76.

Arriondo, L. (2015). De la UCeDe al PRO. Un recorrido por la trayectoria de los militantes de centro derecha de la Ciudad de Buenos Aires. En G. Vommaro y S. Morresi (Eds.), «Hagamos equipo». PRO y la construcción de la nueva derecha en Argentina. Los Polvorines: UNGS Ediciones.

Bargel, L. (2009). Socialisation politique. En O. Fillieule, Mathieu, L. y Péchu, C. (Eds.), Dictionnaire des mouvements sociaux. París: Presses de Science Po.

Beltrán, M. (2013). La Franja. De la experiencia universitaria al desafio del poder. Buenos Aires: Aguilar.

Binder, A. y Wood, K. (2013). Becoming right. How campuses shape young conservatives. Princeton: Princeton University Press.

Blanco, R. (2016). Escenas militantes. Lenguajes, identidades políticas y nuevas agendas del activismo estudiantil universitario. Buenos Aires: Grupo Editor Universitario.

Blanco, R. y Vommaro, P. (2017). Otros caminos, otros destinos. Transformaciones en los espacios y prácticas cotidianas de participación juvenil en los años ochenta. En Vázquez, M., Vommaro, P., Núñez, P. y Blanco, R. (Comps.), Militancias juveniles en la Argentina democrática. Trayectorias, espacios y figuras de activismo. Buenos Aires: Imago Mundi.

Bonaldi, P. (2006). Hijos de desaparecidos. Entre la construcción de la política y la construcción de la memoria. En E. Jelin y D. Sempol (Eds.), El pasado en el futuro: los movimientos juveniles. Buenos Aires: Siglo XXI.

Borobia, R., Kropff, L., y Nuñez, P. (2013). La participación política juvenil post2001/3. En R. Borobia, L. Kropff, y P. Nuñez (Eds.), Juventud y participación política. Más allá de la sorpresa. Buenos Aires: Noveduc.

Buchbinder, P. (2010). Historia de las universidades argentinas. Buenos Aires: Sudamericana.

Califa, J. (2014). La socialización política estudiantil en la Argentina de los sesentas. La Universidad de Buenos Aires. Perfiles educativos, 36(146), 98-113. 
Citro, S. (2009). El rock como ritual adolescente. Trasgresión y realismo grotesco en los recitales de Bersuit. TRANS. Revista transcultural de música, 12, 1-17.

Cháves, M. (2007). Los espacios urbanos de jóvenes en La Plata. Avuá. Revista de Antropología, 11, 213-215.

Fillieule, O. y Pudal, B. (2010). Sociologie du militantisme. Problématisations et déplacement des méthodes d'enquête. En É. Agrikoliansky, I. Sommier y O. Fillieule, (Eds.), Penser les mouvements sociaux. Conflits sociaux et contestations dans les societies contemporaines. París: La Découverte Recherches.

Fillieule, O., 2012. Travail, familie, politisation. En I. Sainsaulieu y M. Surdez (Eds.), Sens politiques du travail. París: Armand Colin Recherches.

Fillieule, O., 2013. Political socialization and social movements. En D. Snow, Della Porta,D., Klandermans, B. y McAdam, D. (Eds.), The Wiley-Blackwell Encyclopedia of Social and Political Movements. Oxford: Wiley.

Flax, R. (2013). La representación de los jóvenes en la retórica presidencial de Cristina Fernández de Kirchner. En M. Vitale y P. Salazar (Eds.), Rhetoric South America. Cape Town: Africa Rhetoric Publishing.

Fuentes, S. (2017). Elegir la universidad privada en Buenos Aires: espacialización de la elección en contextos de diversificación. Educação e Pesquisa, 43(4), 957-972.

Gessaghi, V. (2015). «Ser sencillo, ser buena persona»: clasificaciones morales y procesos de distinción en las experiencias educativas de la «clase alta» argentina. Pro-Posições, 77(26), 33-50.

Gessaghi, V. (2016). La educación de la clase alta argentina. Entre la herencia y el mérito. Buenos Aires: Siglo XXI.

Grandinetti, J. (2015). «Mirar para adelante». Tres dimensiones de la juventud en la militancia de Jóvenes PRO. En G. Vommaro y S. Morresi (Eds.), «Hagamos equipo». PRO y la construcción de la nueva derecha en Argentina. Los Polvorines: Ediciones UNGS.

Grandinetti, J. (2016). ¿CCómo se hace un Joven PRO? La construcción sociocultural de la militancia juvenil del PRO en la Ciudad de Buenos Aires. Tesis de Maestría en Ciencia Política. Buenos Aires: Universidad Nacional de San Martín.

Grandinetti, Juan (2019). Sociabilidad católica y práctica política en la organización juvenil del partido Propuesta Republicana (PRO). Revista de Sociologia e Política, 27(70). En prensa.

Kozel, A. (1996). Los jóvenes y la política. Modulaciones de un escepticismo general. En M. Margulis (Ed.), La juventud es más que una palabra. Buenos Aires: Biblos. Lagroye, J. (1994). Sociología política. México: Fondo de Cultura Económica.

Mattina, G. (2015). De «Macri» a «Mauricio». Una aproximación a los mecanismos de constitución pública del liderazgo político en la Argentina contemporánea. En G. Vommaro y S. Morresi (Eds.), «Hagamos equipo». PRO y la construcción de la nueva derecha en Argentina. Los Polvorines: Ediciones UNGS. 
Mauro, S. (2015). La transformación del sistema político argentino y sus nuevos actores. La construcción de Propuesta Republicana como partido político nacional (2003-2013). Analecta Política, 5(9), 407-430.

Morresi, S. (2015). «Acá somos todos democráticos». El PRO y las relaciones entre la derecha y la democracia en Argentina. En G. Vommaro y S. Morresi (Eds.), "Hagamos equipo». PRO y la construcción de la nueva derecha en Argentina. Los Polvorines: Ediciones UNGS.

Natanson, J. (2013). El retorno de la juventud. Movimientos de repolitización juvenil en nuevos contextos urbanos. Nueva Sociedad, 243, 92-103.

Offerlé, M. (2004). Los partidos políticos. Santiago: LOM Ediciones.

Palacios-Valladares, I. (2016). With or without them. Contemporary student movements and parties in the southern cone. The Latin Americanist, 60(2), 243-268.

Picotto, D. y Vommaro, P. (2010). Jóvenes y política: las agrupaciones estudiantiles independientes de la Universidad de Buenos Aires. Nómadas, 32, 149-161.

Rodríguez, G. (2013). ¿Heredarás el viento? Liderazgos fundacionales y cambio generacional en el proceso político argentino a treinta años de 1983. Observatorio Latinoamericano, 12, 276-290.

Rodríguez, L. (2015a). Iglesia y educación en la Argentina durante la segunda mitad del siglo XX. Cadernos de História da Educação, 14(1), 263-278.

Rodríguez, L. (2015b). Las elites católicas y la fundación de universidades (1958-1983). Actas de la 2da Reunión Internacional sobre Formación de las Elites: enfoques y avances de investigación en el estudio relacional de las desigualdades. Buenos Aires: FLACSO.

Sawicki, F. (1997). Les réseaux du Parti Socialiste: sociologie d'un milieu partisan. Paris: Belin.

Sawicki, F. (2001). Les parties politiques comme entreprises culturelles. En D. Cefaï, ed., Les cultures politiques. París: PUF.

Sawicki, F. (2011). Para una sociología de los entornos y las redes partidistas. Revista de Sociología, 25, 37-53.

Sawicki, F. y Siméant, J. (2009). Décloisonner la sociologie de l'engagement militant. Note critique sur quelques tendances récentes des travaux français. Sociologie $d u$ travail, 51(1), 97-125.

Semán, P. y Vila, P. (1999). Rock chabón e identidad juvenil en la Argentina neoliberal. En D. Filmus (Ed.), Los 90. Política, sociedad y cultura en América Latina y Argentina en fin de siglo. Buenos Aires: FLACSO-Eudeba.

Sidicaro, R. y Tenti Fanfani, E. (Comps.) (1998). La Argentina de los jóvenes. Entre la indiferencia y la indignación. Buenos Aires: UNICEF-Losada.

Svampa, M. (2001). Identidades astilladas. De la patria metalúrgica al heavy metal. En M. Svampa (Ed.), Desde abajo. La transformación de las identidades sociales. Buenos Aires: Biblos.

Talento, M. (1988). Derechización en la universidad. El caso argentino. Nueva Sociedad, 18, 123-133. 
Tiramonti, G. y Ziegler, S. (2008). La educación de las elites. Aspiraciones, estrategias y oportunidades. Buenos Aires: Paidós.

Urresti, M. (2000). Paradigmas de participación juvenil: un balance histórico. En S. Balardini (Ed.), La participación social y política de los jóvenes en el horizonte del nuevo siglo. Buenos Aires: CLACSO.

Vázquez, M. (2009). La política desde abajo: narrativas militantes de jóvenes desocupados y desocupadas en Argentina. Revista Latinoamericana de Ciencias Sociales, Niñez y Juventud, 7(1), 423-455.

Vázquez, M. (2013). En torno a la construcción de la juventud como causa pública durante el kirchnerismo: principios de adhesión, participación y reconocimiento. Revista Argentina de Estudios de Juventud, 1(7), 1-28.

Vázquez, M. (2014). «Militar la gestión»: una aproximación a las relaciones entre activismo y trabajo en el Estado a partir de las gestiones de gobierno de Cristina Fernández de Kirchner en Argentina. Apuntes, 41(74), 71-102.

Vázquez, M. y Cozachcow, A. (2017). Activismo juvenil en partidos con gestiones de gobierno a nivel subnacional en Argentina (2007-2015). Revista de Sociologia e Política, 64(25), 47-72.

Vázquez, M. y Vommaro, P. (2012). La fuerza de los jóvenes: aproximaciones a la militancia kirchnerista desde La Cámpora. En A. Natalucci y G. Pérez (Eds.), Vamos las bandas. Organizaciones y militancia kirchnerista. Buenos Aires: Nueva Trilce.

Vázquez, M., Rocca Rivarola, D., y Cozachcow, A. (2018). Compromisos militantes en juventudes político-partidarias (Argentina, 2013-2015). Revista Mexicana de Sociología, 80(3), 519-548.

Vázquez, M., Vommaro, P., Núñez, P., y Blanco, R. (Eds.) (2017). Militancias juveniles en la Argentina democrática. Trayectorias, espacios y figuras de activismo. Buenos Aires: Imago Mundi.

Vommaro, G. (2015). Contribución a una sociología política de los partidos. Los mundos sociales de pertenencia y las generaciones políticas de PRO. En G. Vommaro y S. Morresi (2015) (Eds.), «Hagamos equipo». PRO y la construcción de la nueva derecha en Argentina. Los Polvorines: UNGS Ediciones.

Vommaro, G. (2015). Contribución a una sociología política de los partidos. Los mundos sociales de pertenencia y las generaciones políticas de PRO. En G. Vommaro y S. Morresi (Eds.), «Hagamos equipo». PRO y la construcción de la nueva derecha en Argentina. Los Polvorines: UNGS Ediciones.

Vommaro, G. (2017). La larga marcha de Cambiemos. La construcción silenciosa de un proyecto de poder. Buenos Aires: Siglo XXI.

Vommaro, G. y Morresi, S. (2014). Unidos y diversificados: la construcción del partido PRO en la CABA. Revista SAAP, 8(2), 375-417.

Vommaro, G. y Morresi, S. (2015). «La Ciudad nos une». La construcción de PRO en el espacio político argentino. En G. Vommaro y S. Morresi (Eds.), «Hagamos equipo». PRO y la construcción de la nueva derecha en Argentina. Los Polvorines: Ediciones UNGS. 
Vommaro, P. y Vázquez, M. (2008). La participación juvenil en los movimientos sociales autónomos de la Argentina. El caso de los Movimientos de Trabajadores Desocupados (MTDs). Revista Latinoamericana de Ciencias Sociales, Niñez y Juventud, 6(2), 485-522.

Walter, R. (1968). Student politics in Argentina. The University Reform and its efects, 19181964. Nueva York: Basic Books Publishers.

Yann, C. (2017). El movimiento estudiantil de la Universidad de Buenos Aires en el final de la última dictadura (1982-83). Sociohistórica, 40, 1-17.

\title{
Palabras clave
}

partidos políticos - socialización política - universidad - centros de estudiantes - activismo

\section{Keywords}

political parties - political socialization - university - student unions activism

\begin{abstract}
This article aims to analyze the forms of participation, political socialization and recruitment of «Propuesta Republicana» (PRO) party's young activists in the student unions at two universities based in the City of Buenos Aires: the University of Buenos Aires, and the Argentine Catholic University. It examines how activists' action repertoires and interpretive frames are shaped by their sociability and by the party's political culture. The article shows that activists' sociocultural and political proximity (or distance) from these institutions allows us to understand the characteristics of their engagement in the student unions at each of these universities. Our findings are based on fieldwork conducted between 2013 and 2015 using qualitative research methods such as in-depth interviews, direct observation in party events, and documents and web pages content analysis.
\end{abstract}

